Early Child

Development

and Care
Early Child Development and Care

ISSN: 0300-4430 (Print) 1476-8275 (Online) Journal homepage: https://www.tandfonline.com/loi/gecd20

\title{
Scientific literacy in the early years - practical work as a teaching and learning strategy
}

\section{Sara Pereira, Maria José Rodrigues \& Rui Marques Vieira}

To cite this article: Sara Pereira, Maria José Rodrigues \& Rui Marques Vieira (2020) Scientific literacy in the early years - practical work as a teaching and learning strategy, Early Child Development and Care, 190:1, 64-78, DOI: 10.1080/03004430.2019.1653553

To link to this article: https://doi.org/10.1080/03004430.2019.1653553

\section{册Published online: 18 Sep 2019.}

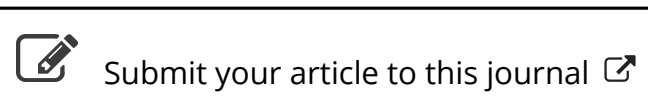

\footnotetext{
III Article views: 77
}

Q View related articles $₫$

View Crossmark data \ulcorner 


\title{
Scientific literacy in the early years - practical work as a teaching and learning strategy
}

\author{
Sara Pereira ${ }^{\mathrm{a}}$, Maria José Rodrigues $\mathbb{(}^{\mathrm{b}}$ and Rui Marques Vieira (1) ${ }^{\mathrm{c}}$ \\ ${ }^{a}$ Departamento de Educação e Psicologia, Universidade de Aveiro, Aveiro, Portugal; ${ }^{b}$ Departamento de Ciências da \\ Natureza, Escola Superior de Educação do Instituto Politécnico de Bragança, Bragança, Portugal; 'Departamento de \\ Educação e Psicologia, Universidade de Aveiro, Aveiro, Portugal
}

\begin{abstract}
Science education become one prioritie of modern societies, with the purpose of forming scientifically literate youth and adults. They play an active role in solving the problems existing in society, making critical and informed decisions. In this paper we discuss the need for scientifically literate citizens and the relevance of practical work as a key strategy for science learning in the early years. We'll describe the investigative process which supported in real-life educational contexts of a set of Didactic Strategies. We'll focus on the results of the 'Materials Lotto' detailing the results in science teaching and learning in kindergarten. The results show that children mobilize a wide array of skills and attitudes/ beliefs, showing scientific knowledge at different degrees of complexity. We concluded that practical work in science education in the early years is an effective strategy for science teaching and learning, as groundwork for future science literacy of kindergarten children.
\end{abstract}

\section{ARTICLE HISTORY}

Received 1 September 2018

Accepted 1 December 2018

\section{KEYWORDS}

Science education; practical work; science-technologysociety education; kindergarten; scientific competence; science literacy

\section{Science education in the early years}

Aware of the evolution of science and technology in the last few years, and the effects this has on society, it is necessary to understand the extent to which children and youth education provide a sound basis for their scientific literacy - so as to allow them to be an integrative part of a global society.

A review of available research allows us to understand the debate surrounding these matters, mostly regarding teacher training and development. Some kindergarten teachers do have a solid scientific background to support the implementation of adequate and motivating scientific activities, based on interactionist, hands-on and socio-constructivist approaches. These practices will contribute to the development of autonomous, cooperative, active and responsible citizens. However, other kindergarten teachers may be hampered by insufficient scientific knowledge and with professional instability. The lack of adequate teaching resources for the early years is another factor that serves to hinder science education in early years settings. Practical work in science in the early years may later favour choosing a scientific career and will allow for an understanding of science as a way to explain the world around us. It is, we believe, a strong asset to children's development and to their integration in modern society.

Osborne (2008) understands that science education is in need of a new vision, as society demands a new way to think about science. We should, therefore, believe that this is also a challenge for pre-school science. In the case of Portugal, science education is embodied in the curricular guidelines for pre-school education, included in the domain called Knowledge About the World. It is presented as a structuring axis between the different curricular domains that should 
allow an integrated, trans-disciplinary and transversal approach to different scientific concepts. Early years science projects are based on the works of authors such as Coltman (1999) and Millar and Osborne (1998), who state that (i) science should be enjoyable; (ii) investigative competencies should be identified and developed; (iii) hands-on experiences are imperative in early science; (iv) play is a way to learn about science, by conducting small investigations in the classroom; (v) science allows for the development of children's natural curiosity; (vi) it develops a careful way to look at the world; (vii) it promotes the use of language to describe phenomena; (viii) it allows for the use and practice of measuring skills and the use of number, and (ix) it provides opportunities to interact and investigate while exploring a great variety of natural phenomena. These authors also state that these are essential conditions to allow children to build basic representations and concepts regarding science and technology. So, science in the early years promotes the development of science literacy, which is paramount for their development as students and also as responsible, informed and autonomous citizens.

Martins (2002) justifies the importance of early science at two levels. First, at a personal level, it is considered as a stepping stone to the understanding of the world around us. Second, at a social level, it is important to develop science itself through the diffusion of scientific and technical careers, which are necessary as part of the solution for some of the world's problems. Similarly, Fumagalli (1998) and Martins et al. (2006) highlight three social reasons that justify science education in the early years. First, children are entitled to learn, so to deprive them of the scientific component of learning is depriving them of a right which is theirs. Second, culture does include scientific knowledge, so it should be included in school curricula and, third, scientific knowledge allows us to improve the quality of our interaction with others and with the environment. More recently, Martins et al. (2009), based on the studies of Eshach (2006), point out several reasons in favour of early science:

- Children do enjoy observing and trying to understand nature and natural phenomena

- Science education contributes to a positive and informed image about science

- An early exploration of scientific phenomena promotes a better understanding of concepts later taught in school

- The adequate use of scientific language with children may play a role in the development of scientific concepts

- Children are able to understand some scientific concepts and to think scientifically, and

- Science education allows for the development of scientific reasoning skills.

Besides developing scientific skills, when grounded on a socio-affective approach, science education also promotes the development of scientific attitudes and beliefs as well as certain social behaviours. These can be understood as having a more cognitive dimension (open-mindness, curiosity, creativity, objectivity, intellectual honesty, critical thinking, persistence) and also an affective dimension (respect, tolerance, cooperation, self-confidence). Many of these attitudes are necessary to be scientifically literate. A scientifically literate person should be able to question reality so to make informed decisions about problems that affect him or her, and to be able to contribute to the solution of problems, to be intuitive in an investigative process, to be creative, curious and critical in finding solutions and alternative ways to solve problems (Fialho, 2009). In short, science education in the early years promotes the development of scientific skills such as observing, predicting and explaining the world which are related and interdependent to others such as communicating, learning to learn, autonomy and personal initiative.

\section{Practical work as a teaching and learning strategy}

Science education can be based on different perspectives, as suggested by Cachapuz, Praia, and Jorge (2000): Teaching Trough Transmission, Teaching Through Discovery, Teaching Towards 
Conceptual Change, and Teaching Through Research (TTR). TTR is the perspective which better conforms to contemporary visions of the scientific endeavour, with the needs of today's society and with a science education of a practical nature and being Science-TechnologySociety (STS) orientated.

Cachapuz, Praia, and Jorge (2002) list four arguments in favour of TTR: calling on the need (i) to be inter- and trans-disciplinary in trying to understand the world in its complex and global form, adopting an holistic vision in studying current problems; (ii) to approach daily problem situations which can allow for a solid foundation for the construction of knowledge and to reflect about science processes, technology and its interactions with the environment and society, thus contributing to the development of competencies, skills, attitudes and beliefs; (iii) to adopt a methodological pluralism regarding working strategies mainly considering guidelines relative to practical work and, (iv) to defy classificatory assessment replacing it with formative assessment which involves all intervening parties and considers the diversity of contexts. These are essential aspects of teaching in order to achieve qualitative steps towards better learning and a better way to approach STS issues (Marques \& Paixão, 2009). Seen through this lens, knowledge content is not understood as an end to itself, but considered socially relevant and contributive to solving problems facing society and it will arise in teaching contexts where shared research is experienced.

Education will then transcend merely instructional goals, emphasizing cooperative work and child interaction and thinking skills. According to Pereira and Paixão (2004), while adopting a TTR perspective, it is up to the kindergarten teacher to implement more open and flexible activities, which should be closely related to a given problem-situation. These must be adequately contextualized to each class, focus on daily phenomena, appealing and able to generate discussion.

Practical work, in a child-centered approach, is considered to be the best strategy to promote a scientific and technological education for all since the early years. It allows the building of some understanding, though simplified, about science, its processes and its nature, as well as developing a scientific attitude towards problem-solving (DGIDC, 2006). Practical work is also a teaching strategy that allows to build a closer rapport between children and the kindergarten teacher, blurring any barriers existing in the classroom (Deus \& Neves, 2009). The kindergarten teacher is not considered as a simple medium for knowledge transmission but as a guide for the necessary processes (Ibarra, Arlegui, \& Wilhelmi, 2009).

Hodson (1994) contradicts the idea that practical work is necessarily work involving a laboratory bench and some kind of experimentation. According to this author, practical work would be any kind of activity that requires the student to be active and not passive, consistent with the idea that he learns better through direct experience. Therefore not all practical work involves a laboratory bench. There are alternatives like computerized interactive activities, exploring different materials, case studies, interviews, debates and role-play, essays, posters and scrapbooks, library researches, photo and video documentaries. According to Caamaño (2003) and Martins et al. (2006), practical work may consist of: sensory experiences, observation and illustration activities, practical exercises and investigations or investigative activities, where we could include experimental work. They can and should be diverse in their typology, like exploratory, sorting, illustrative and developing fair tests.

Investigative activities aim at developing students' understanding of processes related to questioning and allowing them to apply it in problem-solving situations that are theoretical or practical in nature and that emerge from their close and familiar contexts and connected to their everyday lives. These activities always involve two kinds of understanding. One conceptual and another processual, which, articulated, would develop cognitive competencies needed to solve problems (Caamaño, 2003; Goldsworthy \& Freasey, 1997; Martins et al., 2006; Miguéns, 1999). 
Through investigative activities, learning is an active process, based on experimentation and discovery, where scientific knowledge can be approached in a concrete and intuitive way (Thouin, 2004). They may inspire and encourage kindergarten teachers to conceive and help children conceive experimental work, by preparing the necessary resources and records. Wellington (1998) and Miguéns (1999) enhance the potential of talk, discussion and imagination when doing practical work. This latter author points three arguments in favour of practical work with small children. At a cognitive level, it may contribute to science understanding and conceptual development. At an affective level, it is engaging. At a developmental level, it develops not only practical skills but a higher level of competency using observation, measurement, prediction and inference which are transferable to other areas of knowledge.

Bóo (2004) points out that scientific skills and attitudes are better revealed when children are engaged on hands-on and minds-on activities, making observations, showing curiosity, giving explanations, cooperating and behaving safely. Martins (2002), based on Goldsworthy and Freasey (1997), presents some basic principles for the implementation of these activities at a kindergarten level: (i) identifying children's previous ideas, (ii) discussing the question-problem, (iii) planning procedures, (iv) predicting results, (v) executing the experiment, (vi) interpreting results; (vii) formulating a conclusion and (viii) stating new questions to investigate. Above all, they should help children develop their ideas and conceptual understandings (Johnston, 2005). For Berezuki, Obara, and Silva (2009), theses practical activities, if conducted in an investigative and problem-solving approach, when well conducted, allow for situations where children may evaluate the adopted resources and procedures, may formulate hypothesis, rethink their ideas, make decisions which, in all, develops their scientific spirit. Miguéns (1991) adds that these activities are opportunities for children, starting from their own ideas and conceptions, to use strategies of science, to recognize other perspectives as useful and to build new and functional conceptions.

In Harlen's perspective (2000), small investigations since the early years are essential for children to explore the real world, prove their ideas and develop them. This author defends that small children should use procedures technics like observation, interpreting information, asking questions, hypothesizing, communicating and planning small investigations. They should define a problem in operational terms, identify what may or may not vary in an investigation and what should be measured, use measurements, comparisons or observations to find the solution for the initial problem.

\section{Science education and the development of competencies}

It is undebatable that the concept of competency has been gaining a progressive relevance in educational contexts, as it is considered to be vital for an individual's full interaction at a personal, social and professional level. So we believe it is important to understand how small children mobilize their skills, attitudes and beliefs to build scientific knowledge.

Several researches identify different components of competency. OECD (Eurydice, 2002) has considered that it comprises a dimension integrating skills, another integrating attitudes/ beliefs and the latest, integrating knowledge. These articulated dimensions represent 'knowledge put to use' (Roldão, 2003), and allow a person to be competent. To be competent means to be able to interact in an effective way in different contexts of one's life, by simultaneously mobilizing attitudinal, procedimental and conceptual components (Zabala \& Arnau, 2007). The articulation between these components is also enhanced in the Benchmarks for Science Literacy (AAAS, 1993).

Learning, then, is an integrated process where attitudes, procedures and knowledge are learned and developed together, as they depend on one another (Jimenez-Aleixandre, 2003), and the interaction among competencies makes knowledge use more effective and adequate. 


\section{Skills}

Skills can be understood as a set of orderly and consecutive actions or tasks, aimed at accomplishing a given objective (Martins et al., 2009), which are necessary to approach the concepts and are instrumental to build knowledge.

In the last decades science education in the UK and USA has been well established, where we can find references to inquiry skills or skills of scientific inquiry (Eshach, 2006; Harlen, 2011a; Harlen \& Qualter, 2009; Johnston, 2011; Jones, Lake, \& Lin, 2008). These are also guidelines found on the Benchmarks (AAAS, 1993) that frame science education in the perspective of inquiry, which is considered, latu sensu, as the 'deployment of inquiry skills in striving to make sense of events and phenomena in the natural and made world around us' (Harlen \& Qualter, 2009, p. 90). We can consider skills to be at a procedimental level or at a thinking level (Caamaño, 2003), as we can distinguish 'inquiry process skills' an 'inquiry reasoning skills' (NRC, 1996).

\section{Attitudes/beliefs}

Attitudes and beliefs are essential for an individual to interact in different social contexts. They are understood as a mindset and a way to act in a given situation (Zabala \& Arnau, 2007). The articulated and interdependent nature of the mobilization of attitudes and beliefs leads us to merge these concepts as inseparable: attitudes/beliefs.

Johnston (2005) makes reference to attitudes of science and attitudes towards science, stating that their development favours cognitive development (Johnston, 2011). Science education should be a privileged way to develop attitudes/beliefs as it no longer can be considered a value free zone (Harlen \& Qualter, 2009), and the kindergarten teacher should be a model of the attitudes he intends children to develop as they are caught, not taught (Harlen, 2000).

Harlen and Qualter (2009) consider that 'attitudes show not in what children can do or know, but in their willingness to use their knowledge or skills where appropriate' (p. 138).

\section{Knowledge}

Knowledge can be understood as basic stones on which scientific interpretations stand and that, interrelated, allow for scientific explanations (Pereira, 2002).

DeBoer (2000) states that 'science content has formed the backbone of science curriculum since its inception' (p. 598) as it is an essential component to scientific literacy and needed to understand and interact with the world. But the challenge for science education stands in finding an equilibrium between curricular content that necessarily includes building content knowledge and developing skills and attitudes/beliefs that are indispensable for the students/future citizens (Bybee, Fensham, \& Laurie, 2009).

Many scientific concepts are of difficult (re)construction by young children, as it is required to grasp different relationships of a quantitative nature that require mathematical tools they do not yet have available (Pereira, 2002). Other concepts require to high an abstraction effort and strong deductive ability that presupposes previous conceptual experience that young children, by age alone, cannot embrace.

Harlen (2011b), Johnston (2011) and Martins et al. (2009) establish as a goal for science education the development of representations (or ideas) that are not too far from scientific concepts that children will find during their schooling, and that can serve as an evaluative frame for a progressive reconstruction. This is an idea Ravanis, Koliopoulos, and Boilevin (2008) share, entitled as precursory models. Above all, science education should allow for children to progress from description to explanation, from small to big ideas and from those that are personal to those that are shared (Harlen \& Qualter, 2009). 


\section{Methodological framework supporting the development of didactic strategies for science education in the early years}

The didactic strategies (DS) were developed based on an Investigation and Research (I\&D) framework, as the initial research intended to develop a set of didactic strategies to promote the teaching and learning of science. We adopted a Design-Based Research (DBR) defined by Plomp (2010, p. 13) as

the systematic study of designing, developing and evaluating educational interventions (such as programs, teaching-learning strategies and materials, products and systems) as solutions for complex problems in educational practice, which also aims at advancing our knowledge about the characteristics of these interventions and the processes of designing and developing them.

Many researchers today look for more pragmatic approaches to research that have a more firm investment from professionals that implement innovative interventions in real educational contexts, from where they can draw elements to refine them. Wang and Hannafin (2005) have conceived DBR has a sequence of systematic processes of $I \& D$, emphasizing the close relationship between the conception of the new intervention and the investigative activity, where investigators also assume a position of designers, adopting a hybrid methodology that is supported by methods and processes of those fields.

Regarding the teaching and learning of science, DS has been defined as an instrument that both promotes the mobilization and development of children's scientific competencies and as curricular innovation, drawing from kindergarten teachers' practices. These are articulated and complementary goals to the teaching and learning of science.

The main focus in developing DS with this purpose is in defining their characteristics, especially when they are aimed at 3-5 year old children.

Work undertaken by Tenreiro-Vieira and Vieira (2004) in a context of teacher training programmes allowed them to define a set of features CTS resources and DS should respect: (i) consider students' previous ideas; (ii) contextualize science teaching by exploring problem-situations that allow students to learn science concepts and processes while trying to find answers; (iii) focusing on STS when they help students to grasp the complexity and globalism of the world; (iv) appeal to the development of critical thinking skills, allowing for rational and responsible answers; (v) appeal to a methodological pluralism, allowing for a variety of investigative ways to approach a problem and to mobilize and develop thinking skills and to build knowledge. These are some of the recommendations of other authors such as Afonso (2008), Harlen (2011b), Johnston (2011), Martins (2002) and Reis (2008).

Curriculum materials should promote teacher learning in addition to student learning, as so they can be considered in a perspective of educative curriculum materials. Davis and Krajcik (2005) present a set of design heuristics they should respect: (i) allow teachers to anticipate and interpret what students think or do during the activities; (ii) support teachers' conceptual learning; (iii) include linkages for them to establish connections with other content units of the curriculum; (iv) clarify and represent the curriculum, and (v) promote what Brown (2009) defined as the teacher's pedagogical design capacity.

According to Bóo (2004), the efficacy of the DS will depend on features such as (i) promoting a safe yet engaging environment for the children; (ii) being challenging; (iii) being cognitively challenging; (iv) support children's development, and (v) being adequate to different children. Johnston (2005) also enhanced the need for a playful approach to inquiry in the early years. Children should explore the world in order to approach scientific concepts and to develop skills and attitudes/ beliefs, and toys can serve as resources which allow children to build ideas and to mobilize scientific competencies. This playful approach should not oversimplify the way children are exposed to science in a debate of 'education versus entertainment' (McCrory, 2011), but we should adopt engagement hooks which allow children to simultaneously mobilize cognitive and affective processes that contribute to learning. 
These are guidelines also found in documents like 'Resources for Teaching Elementary School Science' (NSRC, 1996), 'Science for All Children' (NSRC, 1997) and 'Inquiry and the National Science Education Standards' (NRC, 2000), available to the American community upon the publication of the Standards, and in other authors like Millar (2010).

\section{The components of didactic strategies}

In our understanding there should be three main components DS. The Conceptual Framework is considered a teacher training component which includes a thorough explanation of the concepts, to support the kindergarten teacher's practices, as well as known misconceptions and research references. This is important so to strengthen kindergarten teachers' content and pedagogical knowledge. The Teacher Guide proposes a way to approach those concepts with 3-5 year old children, through practical explorations. It presents the exploration's objectives, concepts and teaching, learning and assessment strategies. It is a framework in the form of a consistent plan with enough flexibility that the explorations can be adapted to different educational contexts. They also present examples of questions for the kindergarten teacher to ask children during the exploration so to stimulate their thoughts and help them progress in their ideas. As previously explained, the Didactic Resources themselves are essential components to the teaching and learning of science and are a major component at the practical level of science.

The Teacher Guides were developed according to guidelines from authors such as Bóo (2006), Harlen and Qualter (2009), Johnston (2011) and Martins et al. (2006, 2009), who have been focusing on science education in the early years.

They include the first section of information for the kindergarten teacher regarding each DS, detailing its goals (in terms of its central and defining content knowledge), the main keywords, a description of the resources included and ways for the children to record both their previous ideas and their observations.

They then present an exploration that includes several major steps in which to involve children: an contextualization strategy (e.g. a Concept Cartoon) that allows children to discuss a problem-situation and try to explain their (previous) ideas, which leads to a record of those ideas.

At this phase, the kindergarten teacher is able to increase access to the children's thinking. Depending on the nature of any given activity, children can be challenged to organize a planning board. They will then do the experimentation (of what can be any type of practical activity such as a sensory experience, an observation and illustration activity, a practical exercise, an investigation or even experimental work), and afterwards record their observations and compare them with their previous records, discussing and trying to explain any differences between them. This exploration ends with a thorough systematization and clarification of ideas, or, in rigour, of the concepts, which is also when children can propose new explorations. The teacher should, at this final stage, be able to assess children's learning, by using other resources included in the DS.

They then present another section of information for the kindergarten teacher. It details what 3-5 year old children should be able to learn in terms of content knowledge, describing the ideas they can construct or (re)construct. It also presents a set of extension activities, stemming from the one they just participated in that may allow children to build upon the knowledge they constructed.

\section{The development of didactic strategies}

From the ten DS initially developed, we selected 'Materials Lotto' as an illustrative example of the work undertaken in one of the original investigations that support this paper (Pereira, 2012), and 
we now describe.

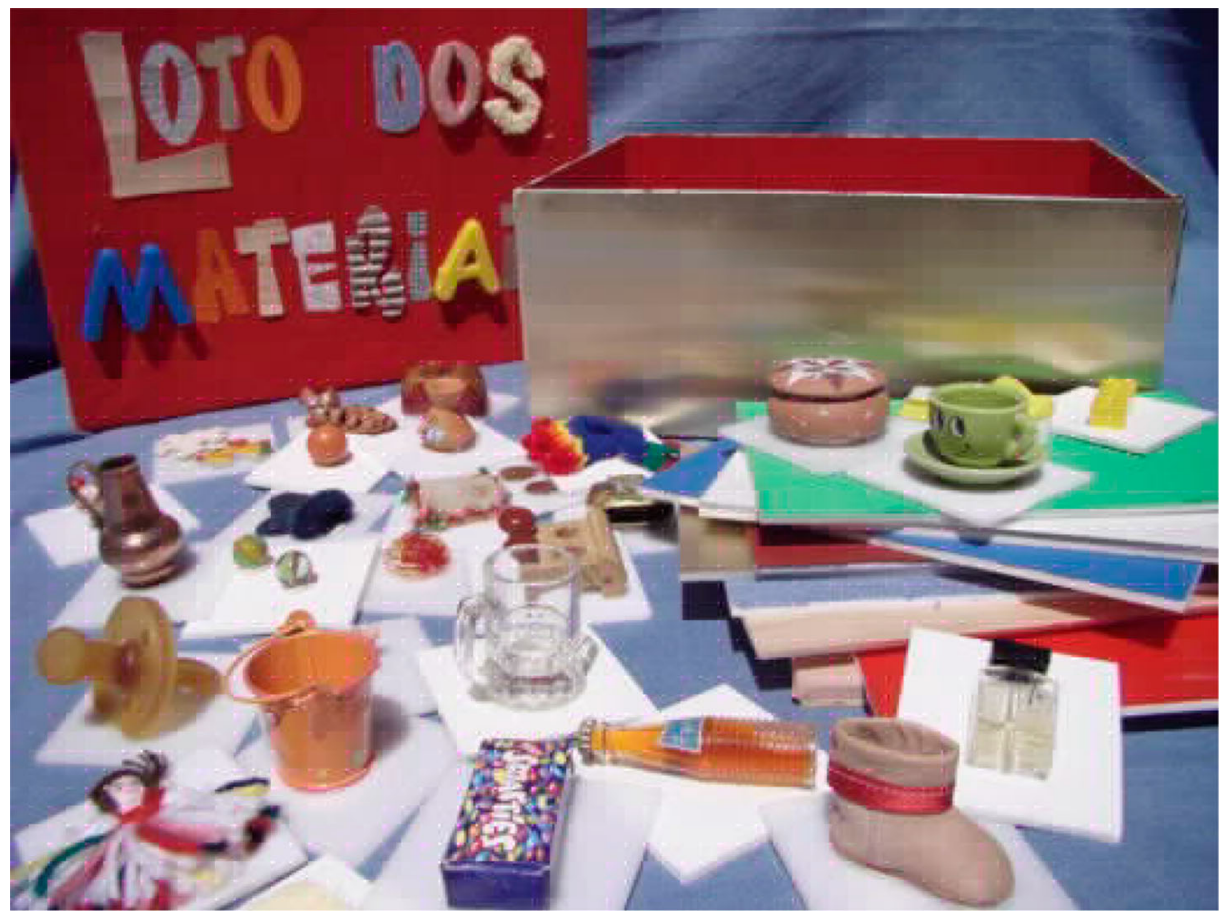

The main goal of this DS is for children to identify the materials from which different objects are made of. In terms of learning outcomes, the kindergarten teacher is provided with a list of content knowledge children may be able or are expected to (re)construct when participating in this DS, shown in an order of growing complexity:

- objects are made of materials;

- objects can be made of one or more than one material;

- there are different materials (e.g. wood, metal, etc.);

- materials can be of natural or non-natural origin;

- natural materials can be of animal, vegetable or mineral origin;

- materials (like wool) are obtained from raw-materials (like sheep fur) to make objects (like mittens), and may be altered during the process;

- objects with the same function can be made of different materials;

- the same material can be used to make different objects;

- the same material can have different appearances (like different colours in metals, clay, fabrics, etc.);

- materials have specific properties (like, elasticity, permeability, texture, etc.);

- we can choose the materials used to make objects according to their properties and the object's function.

The kit of didactic resources included:

- a suggestion for a contextualization strategy (which will be later described);

- a set of nine bases made of nine different materials (plastic, clay, paper/card, rubber, skin/fur, glass, etc.) or of broader groups of the same material (threads and fabrics: cotton, wool, etc.; metals: copper, aluminium, iron, etc.; wood: eucalyptus, pine, etc.); 
- raw samples of these materials;

- a set of 54 pieces with glued objects (mainly small toys) made from those materials.

- two 'wheels of fortune': one showing nine objects children see and use on a daily basis, and another showing the nine materials existing in the activity.

The exploration begins with eliciting children's ideas about objects and materials and the properties of some familiar materials, through a contextualization strategy. For this purpose, it is proposed that the kindergarten teachers invite children to collect objects and toys from the classroom and to identify the materials they are made of. He will then make out series of objects/toys made of the same material including an 'intruder', which is made of a different one. By manipulating those materials children will be able to find out about some of their physical properties (e.g. elasticity, malleability, transparency, smell, etc.) through their senses and will then be invited to find out which is the intruder and explain why. This exploration and successive comparisons will allow children to begin to relate some of those properties to some materials, becoming more proficient in identifying them later on. To further help them to accomplish that, they should also be engaged in manipulating the samples included on the kit and to compare them to the objects they have at hand and to share their ideas with the other children. Controversy, doubt and disagreement on a given material should be used by the kindergarten teacher to promote discussion and debate. Children should be asked what would happen if a given material (e.g. glass) was to be used to make a given object (e.g. a doll). To be asked to explain why they think a given object/toy is made of that material and what would happen if it was made of any other material. Or to give examples of objects that can be made of that same material.

As children think and talk about the implications of choosing specific materials for objects that have a certain purpose and application the kindergarten teacher is able to gain insight about children's ideas about materials and some of their properties, accessing their prior knowledge and/or preconceptions.

The exploration (the Lotto game itself) may be developed by up to 9 children or teams of children. The kindergarten teacher is able to decide how large of a group of children should be involved in the game according to the children's characteristics, or to choose how many and which boards of materials should be present on the game. Each child/team gets or chooses a base and is asked to identify its material. From this point on they 'play the game'. The kindergarten teacher or one of the children take one piece at a time out of the box. They should all look at it very carefully, identify the material used to make the object glued on it and correspond it to the right base. They can explain to the group which characteristics of that material allows them to identify it. They can manipulate the samples to gather more sensorial information to help them distinguish materials which share similarities. Children should be encouraged to think about changes made to some of the materials that could have been cut, painted, glossed or glued together. The kindergarten teacher has a major role in encouraging them to express and debate their ideas, to establish relationships between other objects from their daily lives and, globally, to (re)construct knowledge by promoting children's mobilization of thinking skills and, inevitably, their attitudes/beliefs.

The game is played until the last piece is extracted, and ends with a summary and systematization of what they learned from this activity, organizing their ideas and assuring there are no misconceptions leading to alternative conceptions.

The assessment activity will allow the kindergarten teacher to further understand the children's knowledge (re)construction after participating in the Loto. It can be developed by children on the same day or when the kindergarten teacher finds it more convenient, with the same groups of children or with smaller ones.

Children will be invited to spin both wheels of fortune, getting a combination of a material and of an object (for example, a ball, shirt or key). They are then asked to explain the reasons why that given object could or could not be made of that given material, basing themselves on the knowledge they have of their properties. This will be used to assess children's learning in terms of knowledge content, 
by eliciting the ideas they were able to (re)construct during the exploration by means of manipulating the existing samples and objects and participating on the debates and brainstorming generated during the game. By doing so, children are trying to correspond that object-material combination to other such combinations in the Lotto, found on the contextualization strategy or in any other phase of this DS. They should effectively transfer the knowledge they were able to (re)construct during the Lotto in order to be competent at doing this. And the kindergarten teacher should be able to understand knowledge children (re)constructed regarding the properties of materials and how they determine the choices we make when we are required to build any given object.

\section{Validation of the didactic strategies}

Validation of the set of DS occurred through a format of network investigation with one of the coauthors of this paper (Rodrigues, 2011), as both doctoral studies had overlapping axis regarding science education on the early years. One was focused on teacher in-service training and the other the development of DS. This methodology was adopted to allow for interactive cycles of design and redesign, which enabled the study of different variables and the identification of contextual limitations that generate more useful and transferable results (Amiel \& Reeves, 2008). Each DS was implemented by two kindergarten teachers in two different contexts, although in this paper we will not focus on the differences found relating context variables. On the first phase, the kindergarten teachers chosen to implement the DS were attending a teacher training programme on science education, while on the second phase they were not.

These implementation sessions were observed, video recorded and then analysed to gather data that enabled to understand how the DS contributed to children's mobilization of science competencies. The exhibition of skills, attitudes and beliefs was inferred from their behaviour, performance and words. The exhibition of knowledge was inferred from their answers throughout the exploration and, moreover, during the assessment strategy, focusing on children's choices and justifications. The analytical process used to gather evidence and infer about a factual exhibition of skills, attitudes/ beliefs and knowledge by the participating children was validated by an outside expert.

\section{Science competencies children exhibited}

The analysis of the data from both validation phases on the 10 DS, and of the 'Materials Lotto' in particular, allows us to consider them as strategies effective for early years science education, with the potential to both mobilize and develop children's competencies and that are, simultaneously, suited to be implemented by kindergarten teachers in different educative contexts. Science competencies exhibited by the children while participating in the exploration of the DS were considered as having been mobilized by them.

We are not able to ascertain if all the children did this mobilization and if those who did it at the same level. We are also not able to state that any kindergarten teachers other than the ones who participated in the original investigation would be able to implement the DS as effectively and with the same results.

\section{Skills exhibited by children}

Regarding the mobilization of skills, our first reference is that gathered data indicates that children exhibited almost all the skills initially defined as accessible for 3-5 year-olds and that should be targeted by the kindergarten teacher.

The one more frequently exhibited was 'comparing and identifying similarities and differences'. This could indicate that this is a more transversal skill, or that this DS demands it more often from children, or, also, that it is articulately mobilized with others or indispensable for the mobilization of others, as discussed before (AAAS, 1993; Jimenez-Aleixandre, 2003; Zabala \& Arnau, 2007). 
Out of the other 9 developed DS in the investigation, the Loto also showed a greater count of evidence regarding the exhibition of different skills. Like, for example, 'Establishing cause-effect relationships', 'Identifying and commenting on regularities and patterns' and 'Describing observations'. These results would seem to indicate that this DS does promote teaching and learning situations where children are confronted with multiple solicitations to mobilize their skills in the context of emergent science. They could also indicate that these are skills inevitably needed to complete the exploration. l.e. they are required to observe the properties of the given materials and to understand the function of the given objects and to relate one with the other. This requires multiple skills as well as, above all, pre-existing knowledge.

Conversely, we were able to observe that skills such as 'Planning a simple experimentation' were not exhibited by the children. This is most certainly due to the fact that this DS (basically playing Lotto) mostly requires forming groups of objects depending on the material they are made of, organizing pre-existing pieces and following basic rules. This confirms that activities of different nature demand the mobilization of different skills (Johnston, 2011; Martins et al., 2009).

We can assume a kindergarten teacher may thwart skills mobilization if he/she restricts children's manipulation of the didactic resources, consequently hindering their mobilization of thinking skills (like 'ordering and serializing') and of process skills (like 'Making simple measurements'). This may happen, for example, when an experimental activity is implemented in the form of a demonstration.

\section{Attitudes/beliefs exhibited by children}

All the attitudes/beliefs predefined were exhibited by children. The one most often observed was 'Performing tasks responsibly'. This may indicate that children were predisposed to perform the tasks associated with the exploration, which might point to high levels of motivation and commitment on their part. Closely related attitudes/beliefs were also observed with a high frequency like 'Showing interest in what they see and observe' and 'enjoying learning'. These can be considered of an emotional nature, and closely related to the enjoyment about what they are doing.

We could also infer, aligned with authors such as Harlen (2011b), Johnston (2011) and Martins et al. (2009), that any attitude/belief demands the articulated mobilization of others and of varied skills and of the knowledge children have already constructed.

'Showing open-mindness', was also exhibited by children in high numbers. In a way this observation contradicts egocentric characteristics of 3-5 year old children who, in general, try to prevail their point of view over others' and over facts they observe. (Harlen \& Qualter, 2009; Hughes, 2010)

One of the less observed was 'Question daily events'. This may suggest that this is an attitude/belief difficult for children to mobilize and that may be dependent on their development and previous experiences, on previous demands for it. It may also be dependent on the way children developed other needed attitudes/beliefs, other skills and on the knowledge they were able to build.

Regarding the attitudes/beliefs dimension, we could assume that in a session where a kindergarten teacher promotes active questioning, favouring open-ended questions, with and among the children it is more likely that children will mobilize attitudes/beliefs such as 'Expressing ideas and opinions' or 'Performing tasks by self-initiative'.

\section{Knowledge exhibited}

The Lotto was the DS which showed a greater number of evidence pointing to forms of manifestation of knowledge by children, having been observed even in other DS exploring related concepts like liquid viscosity, friction, origin of materials.

These results may indicate, first of all, that children were able to exhibit knowledge at different levels of complexity, regarding the exploration. They reinforce the idea that concepts are often intertwined and difficult to compartmentalize, and this is a theme that supports building knowledge on other areas of scientific knowledge. 
For example, 'Materials have specific properties (like, elasticity, permeability, texture, ...)' was observed in all the implementation sessions of all of the $10 \mathrm{DS}$. It sums up the larger number of evidence gathered in the whole of the implementation sessions of the original investigation. Likewise, 'Objects are made of materials' was observed in all but 2 of the 20 implementation sessions.

These results lead us to believe that this DS approaches concepts transversal to many subject areas, should contextual conditions allow for interactions that lead to knowledge (re)building by children.

We can note that 'Materials can be from either natural or non-natural origin' was the only one not to be observed. This may be due to the fact that this is content knowledge too complex for children to grasp. This may be related to factors previously discussed like children's lack of experiences and maturity at this age range (Harlen, 2011b; Johnston, 2011; Martins et al., 2009; Pereira, 2002). The (re)construction of knowledge related to this concept doesn't likely occur intuitively from simple daily observations. It may demand being approached in activities in formal science education settings and it will certainly be progressively rebuild by children throughout their lives (Martins et al., 2009). In all, we are able to say that these children did not show evidence of having built knowledge about this concept, which does not exclude the possibility of doing so while participating in this or any other activity, especially if the kindergarten teacher has a questioning attitude throughout its implementation.

\section{Conclusion}

Our results allow for a highly positive evaluation of the developed DS, and of the 'Materials Lotto' in particular. This would correspond to the evaluation of the efficacy of the DS (Nieven, 2010), as it is focused on the results deriving from their implementation in real-life educational contexts.

The DS were also highly evaluated by the participating kindergarten teachers who implemented them in their educational settings. The 'Materials Lotto' scored 4,8/5 and 5/5 in the different evaluation parameters, regarding all their components.

Throughout the implementation sessions children gave ample evidence of mobilizing their thinking and process skills in order to accomplish the proposed tasks, working responsibly, autonomously an cooperatively. They exhibited the ability to do so at a developmental stage prone to more self-centered attitudes, but, as observed, of a scientific nature also. Evidence was gathered that allows us to believe children were able to reach conclusions by exploring relationships and explanations between ideas and events, having constructed knowledge and understanding. Children exhibited having (re)constructed knowledge at some form, sometimes showing to be new and more complex and observed when we compared different phases of the exploration. Gathered evidence also allows us to verify that knowledge from previous activities was transferred to new ones, as in some cases children based their arguments and predictions on previous observations.

The 'teacher factor' cannot be depreciated as a contextual variable that may inevitably restrict the interactions which occurred during the exploration of the DS, and, inevitably, children's learning and development. We enhance the need for the kindergarten teacher to have a strong content knowledge about the concepts relating to each science activity which will allow for a correct and precise approach to scientific concepts, as it will determine the nature (and accuracy) of the knowledge children will be able to (re)construct. This is the greatest guarantee that science education itself does not hinder its own goals by leading to the construction of alternative concepts, so much more difficult to deconstruct.

To accomplish such a task, it is necessary to teach teachers, developing adequate teacher training programmes strengthening their content and pedagogical knowledge. On the other hand, teaching strategies should be available to kindergarten teachers which are focused on children's understanding and require their scientific knowledge and inquiry processes.

Despite the fact that the kindergarten teacher may be the soft underbelly of the DS, all of the above references allow for a positive evaluation of the developed DS. It shows the potential 
towards science education in the early years which is reinforced by the fact that children were positively engaged throughout their participation and showed they can be competent in science. Also, it contributes towards a more universal science and technological literacy for all.

\section{Disclosure statement}

No potential conflict of interest was reported by the authors.

\section{Notes on contributors}

Sara Pereira is a kindergarten teacher with over 25 years experience working with 3-5 year olds in kindergarten schools integrated in the Ministry of Science and Education network. Her areas of interest are science education in the early years and teacher training.

Maria José Rodrigues is professor at the School of Education of the Polytechnic Institute of Bragança. Her research interests include science education from an early age in the perspective of Science-Technology-Society, and has published several papers in this area. She has over 20 years of teaching experience and has collaborated in several research project proposals.

Rui Marques Vieira is professor in University of Aveiro and teaches courses in teacher education. He has been involved in several national and international projects. He has tutored more than $50 \mathrm{MsC}$ students and $10 \mathrm{PhD}$ students. He has published books and several papers and developed several educational resources.

\section{ORCID}

Maria José Rodrigues Escola (1) http://orcid.org/0000-0003-1029-149X

Rui Marques Vieira (D) http://orcid.org/0000-0003-0610-6896

\section{References}

Afonso, M. (2008). A Educação Científica no 1. ${ }^{\circ}$ Ciclo do Ensino Básico. Das teorias às práticas. Porto: Porto Editora.

American Association for the Advancement of Science. (1993). Benchmarks for science literacy. Washington, DC: Author.

Amiel, T., \& Reeves, T. C. (2008). Design-Based research and educational technology: RethinkingTechnology and the research Agenda. Educational Technology \& Society, 11(4), 29-40.

Berezuki, P., Obara, A., \& Silva, E. (2009). Concepções e práticas de professores de ciências em relação ao trabalho prático, experimental, laboratorial e de campo. In C. Márquez, et al. (Coords.) Enseñanza de las Ciencias (pp. 2817-2822). VIII Congreso Internacional sobre Investigación en Didáctica de las Ciencias. Barcelona: Institut de Ciències de I'Educació de la Universitat Autònoma de Barcelona.

Bóo, M. (2006). Science in the early years. In W. Harlen (Ed.), ASE guide to primary science education (pp. 124-132). Hatfield: Association for Science Education.

Bóo, M. D. (2004). Using science to develop thinking skills at key stage I. London: David Fulton Publisher.

Brown, M. (2009). The teacher-tool relationship: Theorizing the design and use of curriculum materials. In J. T. Remillard, B. A. Herbel-Eisenmann, \& G. M. Lloyd (Eds.), Mathematics teachers at work: Connecting curriculum materials and classroom instruction (pp. 17-36). New York: Routledge.

Bybee, R., Fensham, P., \& Laurie, R. (2009). Scientific literacy and contexts in PISA 2006 science. Journal of Research in Science Teaching, 46(8), 862-864.

Caamaño, A. (2003). Los trabajos prácticos en Ciencias. In M. P. Jiménez et al. (Coords.), Enseñar ciencias (pp. 95-118). Barcelona: Editorial Graó.

Cachapuz, A., Praia, J, \& Jorge, M. (2000). Perspectivas do ensino das Ciências. In A. Cachapuz (Ed.), Formação de professores - Ciências - Textos de Apoio, no 1. Porto: Centro de Estudos de Educação em Ciência.

Cachapuz, A., Praia, J., \& Jorge, M. (2002). Ciência, Educação em Ciência e Ensino das Ciências. Lisboa: Ministério da Educação, Instituto de Inovação Educacional.

Coltman, P. (1999). In search of the elephant's child: Early years science. In D. Whitebread (Ed.), Teaching and learning in the early years (pp. 243-254). Londres: Routledge.

Davis, E., \& Krajcik, J. (2005). Designing educative curriculum materials to promote teacher learning. Educational Researcher, 34(3), 3-14.

DeBoer, G. (2000). Scientific literacy: Another look at Its Historical and contemporary Meanings and Its relationship to science education Reform. Journal of Research in Science Teaching, 37(6), 582-601. 
Deus, H. M., \& Neves, I. P. (2009). Trabalho experimental e relações intradisciplinares no ensino/aprendizagem das ciências: Um estudo centrado na formação inicial de professores do $1^{\circ}$ Ciclo do Ensino básico. In F. Paixão \& F. R. Jorge (Coords.), Educação e Formação: Ciência, Cultura e Cidadania (pp. 537-545). XIII Encontro Nacional de Educação em Ciências. Castelo Branco: Instituto Politécnico de Castelo Branco, ESE.

Direcção Geral de Inovação e Desenvolvimento Curricular. (2006). Princípios e Sugestões para a gestão do currículo do $1^{\circ}$ ciclo: Estudo do Meio - Ensino das Ciências. Lisboa: Ministério da Educação, DGIDC. Retrieved from www.dgidc.min-edu. pt/basico/Documents/principios_sugestoes_EM.doc

Eshach, H. (2006). Science literacy in primary schools and pre-schools. Holanda: Springer.

Eurydice. (2002). Key competencies. A developing concept in general compulsory education. Brussels: Eurydice.

Fialho, I. (2009). Ensinar ciência no pré-escolar. Contributos para aprendizagens de outras áreas/domínios curriculares. Relato de experiências realizadas em jardins-de-infância. In C. Márquez, et al. (Coords.), Enseñanza de las ciencias (pp. 5-8). VIII Congreso Internacional sobre Investigación en Didáctica de las Ciencias. Barcelona: Institut de Ciències de l'Educació de la Universitat Autònoma de Barcelona.

Fumagalli, L. (1998). O ensino das Ciências Naturais ao nível fundamental da educação formal: Argumentos a seu favor. In H. Weissmann (Org.), Didáctica das Ciências Naturais. Contribuições e reflexões (pp. 13-29). Porto Alegre: Artmed.

Goldsworthy, A., \& Freasey, R. (1997). Making sense of Primary science Investigacions. Hatfield: Association for Science Education.

Harlen, W. (2000). The teaching of science in primary schools. London: David Fulton Publishers.

Harlen, W. (2011a). What are children achieving? In W. Harlen (Ed.), ASE guide to primary science education (pp. 2-9). Hatfield: Association for Science Education.

Harlen, W. (2011b). Why is learning science important in primary schools? In W. Harlen (Ed.), ASE guide to primary science education (pp. 2-9). Hatfield: Association for Science Education.

Harlen, W., \& Qualter, A. (2009). The teaching of science in primary schools. Oxon: David Fulton Publishers.

Hodson, D. (1994). Hacia un enfoque más crítico del tabajo de laboratorio. Enseñanza de las Ciencias, 12(3), $293-313$.

Hughes, F. (2010). Children, play, and development. Los Angeles: SAGE Publications.

Ibarra, J., Arlegui, J., \& Wilhelmi, M. (2009). La actividad experimental en educación primaria: Restricciones y retos. In C. Márquez, et al. (Coords.), Enseñanza de las Ciencias (pp. 1181-1187). VIII Congreso Internacional sobre Investigación en Didáctica de las Ciencias. Barcelona: Institut de Ciències de l'Educació de la Universitat Autònoma de Barcelona.

Jimenez-Aleixandre, M. P. (2003). El aprendizaje de las ciencias: Construir y usar herramientas. In M. P. Jimenez-Aleixandre (Coord.), Enseñar ciencias (pp. 13-32). Barcelona: Editorial Graó.

Johnston, J. (2005). Early explorations in science. Buckingham: Open University Press.

Johnston, J. (2011). Learning in the early years. In W. Harlen (Ed.), ASE guide to primary science education (pp. 25-33). Hatfield: Association for Science Education.

Jones, I., Lake, V., \& Lin, M. (2008). Early childhood science process skills: Social and developmental considerations. In O. Saracho \& B. Spodek (Eds.), Contemporary perspectives on science and technology in early childhood education (pp. 1740). Charlotte, North Carolina: Information Age Publishing.

Marques, V., \& Paixão, F. (2009). Concepção, implementação e avaliação de uma proposta didáctica para o $1^{\circ} \mathrm{CEB}$ sobre a fome no mundo. In F. Paixão \& F. R. Jorge (Coords.), Educação e Formação: Ciência, Cultura e Cidadania (pp. 410-418). XIII Encontro Nacional de Educação em Ciências. Castelo Branco: Instituto Politécnico de Castelo Branco, ESE.

Martins, I. P. (2002). Educação e Educação em Ciências. Aveiro: Universidade de Aveiro, DDTE.

Martins, I., Veiga, M. L., Teixeira, F., Tenreiro-Vieira, C., Vieira, R. M., Rodrigues, A. V., \& Couceiro, F. (2006). Educação em Ciências e Ensino experimental - Formação de Professores. Lisboa: Ministério da Educação, Direcção-Geral de Inovação e Desenvolvimento Curricular.

Martins, I., Veiga, M. L., Teixeira, F., Tenreiro-Vieira, C., Vieira, R. M., Rodrigues, A. V., ... Pereira, S. (2009). Despertar para a ciência - actividades dos 3 aos 6. Lisboa: Ministério da Educação, Direcção-Geral de Inovação e Desenvolvimento Curricular.

McCrory, P. (2011). Developing interest in science through emotional engagement. In W. Harlen (Ed.), ASE guide to primary science education (pp. 94-101). Hatfield: Association for Science Education.

Miguéns, M. (1991). Actividades práticas na educação em ciências: Que modalidades? Aprender, 14, 39-44.

Miguéns, M. (1999). O Trabalho Prático e o Ensino das Investigações na Educação básica. In M. O. Valente (Org.), Colóquio Ensino experimental e Construção de Saberes (pp. 77-95). Lisboa: Ministério da Educação, Conselho Nacional da Educação.

Millar, R. (2010). Analysing practical science activities to assess and improve their effectiveness. Hatfield: Association for Science Education.

Millar, R., \& Osborne, J. (1998). Beyond 2000: Science education for the future. London: King's College London, School of Education.

National Research Council. (1996). National science education standards. Washington, DC: The National Academies Press. National Research Council. (NRC). (2000). Inquiry and the national science education standards: A guide for teaching and learning. Washington, DC: The National Academies Press. Retrieved from http://www.nap.edu/catalog.php?record_ id $=9596 \#$ toc 
National Science Resources Center, Smithsonian Institution. (1996). Resources for teaching elementar school science. Washington, DC: The National Academies Press. Retrieved from http://books.nap.edu/catalog.php?record_id=4966

National Science Resources Center, Smithsonian Institution. (1997). Science for all children. Washington, DC: The National Academies Press. Retrieved from http://books.nap.edu/openbook.php?isbn=0309052971

Nieven, N. (2010). Formative evaluation in educational design research. In T. Plomp \& N. Nieveen (Eds.), An Introduction to Educational Design Research (pp. 89-102). Enschede, the Netherlands: SLO - Netherlands Institute for Curriculum Development. Retrieved from http://www.slo.nl/downloads/2009/Introduction_20to_20education_20design_ 20research.pdf/

Osborne, J. (2008). Engaing young people with science: Does science education need a new vision? School Science Review, 89(328), 67-74.

Pereira, A. (2002). Educação para a Ciência. Lisboa: Universidade Aberta.

Pereira, S. J. F. M. (2012). Educação em ciências em contexto pré-escolar - Estratégias didáticas para o desenvolvimento de competências. Tese de Doutoramento não publicada. Aveiro: Universidade de Aveiro, Departamento de Educação.

Pereira, P., \& Paixão, M. F. (2004). Reacções de oxidação-redução no ensino básico numa perspectiva CTS. História de vida de uma pilha. In I. P. Martins, M. F. Paixão \& R. M. Vieira (Orgs.), Perspectivas Ciência-Tecnologia-Sociedade na Inovação da Educação em Ciência (pp. 347-351). III Seminário Ibérico CTS no Ensino das Ciências. Aveiro: Universidade de Aveiro, DDTE.

Plomp, T. (2010). Educational design research: An introduction. In T. Plomp, \& N. Nieveen (Eds.), An introduction to educational design research (pp. 9-36). Enschede: SLO - Netherlands Institute for Curriculum Development. Retrieved from http://www.slo.nl/downloads/2009/Introduction_20to_20education_20design_20research.pdf/

Ravanis, K., Koliopoulos, D., \& Boilevin, J.-M. (2008). Construction of a precursor model for the concept of rolling friction in the thought of preschool age children: A socio-cognitive teaching intervention. Research in Science Education, 38(4), 421-434.

Reis, P. (2008). Investigar e descobrir - Actividades para a educação em ciência nas primeiras idades. Chamusca: Edições Cosmos.

Rodrigues, M. J. (2011). Educação em Ciências no Pré-Escolar - Contributos de um Programa de Formação. Tese de Doutoramento não publicada. Aveiro: Universidade de Aveiro, Departamento de Educação.

Roldão, M. C. (2003). Gestão do Currículo e Avaliação de Competências - As Questões dos Professores. Lisboa: Editorial Presença.

Tenreiro-Vieira, C., \& Vieira, R. M. (2004). Produção e Validação de Materiais didácticos de cariz CTS para a educação em Ciências no Ensino básico. In I. P. Martins, F. Paixão, \& R. M. Vieira (Eds.), Perspectivas Ciência-Tecnologia-Sociedade na Inovação da Educação em Ciências (pp. 81-87). III Seminário lbérico CTS no Ensino das Ciências. Aveiro: Departamento de Didáctica e Tecnologia Educativa da Universidade de Aveiro

Thouin, M. (2004). Resolução de problemas científicos e tecnológicos nos ensinos pré-escolar e básico $1^{\circ}$ ciclo. Lisboa: Instituto Piaget.

Wang, F., \& Hannafin, M. (2005). Design-based research and technology-enhanced learning environments. Educational Technology Research and Development, 53(4), 5-23.

Wellington, J. (1998). Practical work in science: Time for a reappraisal. In J. Wellington (Ed.), Practical work in school science: Which way now? (pp. 3-15). London: Routledge.

Zabala, A., \& Arnau, L. (2007). 11 ideas clave como aprender y enseñar competências. 